\title{
A Study on Middle School Students' Physical Fitness Present Situation and Significant Difference in Urumqi
}

\author{
Wenmei Dong ${ }^{1, a}$, Yusufu.Abula ${ }^{2, b}$ and Hui Wang ${ }^{3, c}$ \\ ${ }^{1}$ Physical Education Department of Minzu University of China, Beijing,China \\ 2 Physical Education Department of Xinjiang Normal University,Urumqi ,China \\ ${ }^{3}$ Physical Education Department of Xinjiang Normal University,Urumqi ,China \\ adongwenm@163.com, babula@mail.bnu.edu.cn, c1006363016@qq.com
}

Keywords: physical fitness; significant difference; middle school students

Abstract: This research chose three school in Urumqi, which respectively on behalf of exemplary senior middle school of Xinjiang Uyghur autonomous region, general middle school and rural middle school. The eighth grade students were selected as research object. Using the test method and ANOVA analysis method, two comparison of SPSS 19.0, the research analyzed the physical fitness items on the basis of genuine data. Through comparative significant difference, the research tries to find out the facts that affect physical fitness. The results indicated the physical fitness of rural middle school is better than that of common middle school and key middle school. This shows that student ' $\mathrm{s}$ physical fitness is related to learning pressure on students and the time spent on physical activity.

\section{Introduction}

In recent years, the People's Republic of China pays more attention to teenagers' physical fitness and the test of physical fitness annually. From the view of teenagers' physical fitness situation in Xinjiang province, many scholars analyzed physical fitness according to the ethnic and mainly used the descriptive method, which provided reference for the following research, but they are lack of detailed comparative analysis based on the characteristics of teenagers in different school.

The data of the three middle schools in Urumqi are true, which were collected on the spot, the record being handwritten by teachers. Three middle schools were chosen to represent three levels the advanced middle school, the common middle school and the rural middle schools. The research attempted to solve three problems:1. What are the real physical fitness situation of three middle school ? 2. Are there any significant differences in the physical fitness of the students among the three schools? 3. Whether the significant differences were related to the types of school? Can we find out the factors affecting physical fitness from the causes of differences?

\section{Research Object and Method}

2.1 Research Object. The eighth grade students of the three middle schools were chosen as the research object. The data were collected from the testing in 2015.

Affiliated Middle School of Xinjiang Normal University was built in 1984, which was rated demonstration advanced middle school in 2006. The Seventh School in Urumqi was established in 1962, which had over fifty years history. Dabancheng Middle School was an rural school.

\subsection{Research Methods}

2.2.1 Test Method. According to the test items in 《National Student Physical Health Standard》, boys in the eighth grade take part in the test of 50 meters, standing long jump, 1000 meters, pull up and sitting body flexion, girls in eighth grade take part in test of 50 meters, standing long jump,800 meters, sits-up per minute and sitting body flexion.

2.2.2 Mathematical Statistics. The research used Spss 19.0 to analyze the testing dada from the three middle schools. The ANOVA analysis was used to test whether there are any significant differences in the physical fitness of the students among the three schools. The Post Hoc Test was used to compare the differences between the two groups. 


\section{Research Result and Analysis}

\subsection{Analysis on the Basic Situation of Boys' Physical Fitness in Three Schools}

Table 1 Boys' Physical Fitness in Three Middle Schools in 2015

\begin{tabular}{|c|c|c|c|c|c|c|c|c|}
\hline Year & Item & School & Sample & Average & $\begin{array}{l}\text { Standard } \\
\text { Deviation }\end{array}$ & $\begin{array}{l}\text { Excellent } \\
\text { Rate }\end{array}$ & $\begin{array}{l}\text { Good } \\
\text { Rate }\end{array}$ & $\begin{array}{l}\text { Pass } \\
\text { Rate }\end{array}$ \\
\hline \multirow{15}{*}{2015} & \multirow{3}{*}{$\begin{array}{l}\text { standing } \\
\text { long } \\
\text { jump } \\
(\mathrm{cm})\end{array}$} & Affiliated & 100 & 201 & 32 & $13 \%$ & $42 \%$ & $89 \%$ \\
\hline & & Seventh & 105 & 201 & 22 & $15.2 \%$ & $40 \%$ & $93.3 \%$ \\
\hline & & Dabancheng & 89 & 192 & 24 & $3.7 \%$ & $8.6 \%$ & $65.4 \%$ \\
\hline & \multirow{3}{*}{$\begin{array}{l}\text { sitting } \\
\text { body } \\
\text { flexion } \\
(\mathrm{cm})\end{array}$} & Affiliated & 100 & 6 & 6 & $5 \%$ & $25 \%$ & $89 \%$ \\
\hline & & Seventh & 105 & 7 & 6 & $8.6 \%$ & $40 \%$ & $88.6 \%$ \\
\hline & & Dabancheng & 89 & 7 & 4 & $2.4 \%$ & $6.1 \%$ & $95.1 \%$ \\
\hline & \multirow{3}{*}{$\begin{array}{c}50 \text { meters } \\
\text { (s) }\end{array}$} & Affiliated & 100 & 8.5 & 1.1 & $15 \%$ & $33 \%$ & $88 \%$ \\
\hline & & Seventh & 105 & 8.2 & 1.1 & $33.3 \%$ & $41 \%$ & $96.2 \%$ \\
\hline & & Dabancheng & 89 & 7.9 & 0.8 & $35.8 \%$ & $45.6 \%$ & $96.3 \%$ \\
\hline & \multirow{3}{*}{$\begin{array}{l}\text { Pull up } \\
\text { (Number) }\end{array}$} & Affiliated & 100 & 5 & 5 & $10 \%$ & $13 \%$ & $44 \%$ \\
\hline & & Seventh & 105 & 4 & 4 & $6.7 \%$ & $14.3 \%$ & $33.3 \%$ \\
\hline & & Dabancheng & 89 & 8 & 4 & $18.5 \%$ & $32 \%$ & $81.5 \%$ \\
\hline & \multirow{3}{*}{$\begin{array}{l}1000 \\
\text { meters } \\
(\mathrm{s})\end{array}$} & Affiliated & 100 & 300.2 & 51 & $6 \%$ & $16 \%$ & $69 \%$ \\
\hline & & Seventh & 105 & 279.1 & 39 & $18.1 \%$ & $33.3 \%$ & $77.1 \%$ \\
\hline & & Dabancheng & 89 & 279.7 & 30 & $11.1 \%$ & $12.4 \%$ & $69.1 \%$ \\
\hline
\end{tabular}

From table 1, we can see the results of boys' physical fitness in grade eight in three middle schools in 2015, among which the results of pull up were poor, the results of 1000 meters were relatively poor, while the results of sitting body flexion, standing long jump were basically qualified while the results of 50 meters were better.

The average of boys' pull up in Affiliated Middle School of Xinjiang Normal University was 5 \pm 5 , the pass rate was $44 \%$; the pull up average of boys in the Seventh School in Urumqi was $4 \pm 4$, the pass rate was 33.3\%; the average of boys' pull up in the Dabancheng Middle School was $8 \pm 4$, the pass rate was $81.5 \%$, from which we found that boys in the three schools had poor upper and lower waist strength.

The average of boys ' 1000 meters in Affiliated Middle School of Xinjiang Normal University was 5 ' \pm 51 ', the excellent rate was $6 \%$, the good rate was $16 \%$, the pass rate was $69 \%$; the average of boys' 1000 meters in the Seventh School in Urumqi was 4'39" \pm 39 ", the pass rate was $77.1 \%$; the 1000 meters average of boys in the Dabancheng Middle School was 4'49" \pm 30 ", from which we found that boys in the three schools had poor endurance.

Both the standing long jump and sitting body flexion average were good, which indicated that the lower limbs strength and flexibility of boys in three schools had basically met the requirements of the National Student Physical Health Standard. 
3.2 Analysis on the Basic Situation of Girls' Physical Fitness in Three Schools

Table 2 Girls' Physical Fitness in Three Middle Schools in 2015

\begin{tabular}{|c|c|c|c|c|c|c|c|c|}
\hline Year & Item & School & Sample & $\begin{array}{l}\text { Avera } \\
\text { ge }\end{array}$ & $\begin{array}{l}\text { Standard } \\
\text { Deviatio } \\
\mathrm{n}\end{array}$ & $\begin{array}{l}\text { Excellen } \\
\mathrm{t} \\
\text { Rate }\end{array}$ & $\begin{array}{l}\text { Good } \\
\text { Rate }\end{array}$ & $\begin{array}{l}\text { Pass } \\
\text { Rate }\end{array}$ \\
\hline \multirow{15}{*}{2015} & \multirow{3}{*}{$\begin{array}{l}\text { standing } \\
\text { long jump } \\
\quad(\mathrm{cm})\end{array}$} & Affiliated & 93 & 168 & 19 & $16.1 \%$ & $\begin{array}{c}34.4 \\
\%\end{array}$ & $\begin{array}{c}90.3 \\
\%\end{array}$ \\
\hline & & Seventh & 99 & 168 & 15 & $9.1 \%$ & $\begin{array}{c}36.4 \\
\%\end{array}$ & $\begin{array}{c}93.9 \\
\%\end{array}$ \\
\hline & & $\begin{array}{c}\text { Dabanche } \\
\text { ng }\end{array}$ & 81 & 162 & 13 & $1.9 \%$ & $\begin{array}{c}15.4 \\
\%\end{array}$ & $\begin{array}{c}88.5 \\
\%\end{array}$ \\
\hline & \multirow{3}{*}{$\begin{array}{l}\text { Sitting } \\
\text { body } \\
\text { flexion } \\
(\mathrm{cm})\end{array}$} & Affiliated & 93 & 10.1 & 6 & $15.1 \%$ & $\begin{array}{c}21.5 \\
\%\end{array}$ & $\begin{array}{c}82.8 \\
\% \\
\end{array}$ \\
\hline & & Seventh & 99 & 13.3 & 6 & $14.1 \%$ & $\begin{array}{c}41.4 \\
\%\end{array}$ & $\begin{array}{c}94.9 \\
\%\end{array}$ \\
\hline & & $\begin{array}{c}\text { Dabanche } \\
\text { ng }\end{array}$ & 81 & 9.3 & 5 & $3.8 \%$ & $5.7 \%$ & $\begin{array}{c}88.5 \\
\%\end{array}$ \\
\hline & \multirow{3}{*}{$\begin{array}{c}50 \text { meters } \\
\text { (s) }\end{array}$} & Affiliated & 93 & 9.3 & 0.7 & $8.6 \%$ & $\begin{array}{c}24.7 \\
\%\end{array}$ & $\begin{array}{c}97.8 \\
\%\end{array}$ \\
\hline & & Seventh & 99 & 9.3 & 0.8 & $5.1 \%$ & $\begin{array}{c}26.3 \\
\%\end{array}$ & $\begin{array}{c}93.9 \\
\%\end{array}$ \\
\hline & & $\begin{array}{c}\text { Dabanche } \\
\text { ng }\end{array}$ & 81 & 8.8 & 0.7 & $13.4 \%$ & $\begin{array}{c}44.2 \\
\%\end{array}$ & $\begin{array}{c}96.1 \\
\%\end{array}$ \\
\hline & \multirow{3}{*}{$\begin{array}{l}\text { sits-up } \\
\text { (Number) }\end{array}$} & Affiliated & 93 & 31 & 7 & $3.2 \%$ & $9.7 \%$ & $\begin{array}{c}94.6 \\
\%\end{array}$ \\
\hline & & Seventh & 99 & 36 & 6 & $6.1 \%$ & $\begin{array}{c}22.2 \\
\%\end{array}$ & $99 \%$ \\
\hline & & $\begin{array}{c}\text { Dabanche } \\
\text { ng }\end{array}$ & 81 & 30 & 4 & $0 \%$ & $0 \%$ & $\begin{array}{c}94.1 \\
\%\end{array}$ \\
\hline & \multirow{3}{*}{$\begin{array}{l}800 \\
\text { meters } \\
(\mathrm{s})\end{array}$} & Affiliated & 93 & 259.6 & 38 & $12.9 \%$ & $\begin{array}{c}23.7 \\
\%\end{array}$ & $86 \%$ \\
\hline & & Seventh & 99 & 253.4 & 26 & $9.1 \%$ & $\begin{array}{c}33.3 \\
\%\end{array}$ & $\begin{array}{c}90.9 \\
\%\end{array}$ \\
\hline & & $\begin{array}{c}\text { Dabanche } \\
\text { ng }\end{array}$ & 81 & 240.8 & 19 & $46.1 \%$ & $\begin{array}{c}55.7 \\
\%\end{array}$ & $\begin{array}{c}96.1 \\
\%\end{array}$ \\
\hline
\end{tabular}

From table 2, we can see the results of girls' physical fitness in grade eight in three middle schools in 2015. The average of girls' 800 meters in Affiliated Middle School of Xinjiang Normal University was 4'20' \pm 38 ', the pass rate was $86 \%$; the average of girls' 800 meters in the Seventh School in Urumqi was 4' $14 " \pm 26$ ", the pass rate was $90.9 \%$; the 800 meters average of girls in the Dabancheng Middle School was 4'1" \pm 19 ", the pass rate was $96.1 \%$, from which we found that the endurance of girls in grade eight in the three schools had improved, but the schools still need to strengthen the students' endurance exercises.

The standing long jump average of girls in the Dabancheng Middle School was worse than that of other two schools, the excellent rate was $1.9 \%$, the good rate was $15.4 \%$, which showed that the Dabancheng Middle School should arrange more physical activities to improve strength of the students. The sits-up good rate and pass rate of the three middle were low, the good rate of three schools were $9.7 \%, 22.2 \%$ and $0 \%$, the sits-up excellent rate were $3.2 \%, 6.1 \%$ and $0 \%$, which suggested that most of the girls waist strength was weak, its need to be strengthened by practice.

The Sitting body flexion average was good, which suggested that the endurance was good. The 50 meters average was good, which suggested that the speed was good. 


\subsection{The Significant Difference Analysis Among Boys' Physical Fitness in Three Middle Schools in 2015}

Table 3 ANOVA Analysis among Boys Physical Fitness in 2015

\begin{tabular}{|c|c|c|c|c|c|c|c|}
\hline Year & Item & & $\begin{array}{l}\text { Sum of } \\
\text { square }\end{array}$ & df & $\begin{array}{l}\text { mean } \\
\text { square }\end{array}$ & $\mathrm{F}$ & Sig. \\
\hline \multirow{10}{*}{2015} & \multirow{2}{*}{$\begin{array}{l}\text { standing } \\
\text { long } \\
\text { jump }\end{array}$} & $\begin{array}{l}\text { between } \\
\text { group }\end{array}$ & 4378.286 & 2 & 2189.143 & 2.841 & .060 \\
\hline & & $\begin{array}{l}\text { group within } \\
\text { the statistics }\end{array}$ & 215785.629 & 280 & 770.663 & & \\
\hline & \multirow{2}{*}{$\begin{array}{l}\text { sitting } \\
\text { body } \\
\text { flexion }\end{array}$} & $\begin{array}{l}\text { between } \\
\text { group }\end{array}$ & 194.075 & 2 & 97.029 & 1.949 & .144 \\
\hline & & $\begin{array}{l}\text { group within } \\
\text { the statistics }\end{array}$ & 13937.762 & 280 & 49.778 & & \\
\hline & \multirow{2}{*}{$\begin{array}{c}50 \\
\text { meters }\end{array}$} & $\begin{array}{l}\text { between } \\
\text { group }\end{array}$ & 14.648 & 2 & 7.324 & 7.974 & .000 \\
\hline & & $\begin{array}{l}\text { group within } \\
\text { the statistics }\end{array}$ & 259.934 & 283 & 0.918 & & \\
\hline & \multirow{2}{*}{ Pull up } & $\begin{array}{l}\text { between } \\
\text { group }\end{array}$ & 738.395 & 2 & 369.198 & $\begin{array}{c}18.82 \\
7\end{array}$ & .000 \\
\hline & & $\begin{array}{l}\text { group within } \\
\text { the statistics }\end{array}$ & 5549.706 & 283 & 19.610 & & \\
\hline & \multirow{2}{*}{$\begin{array}{l}1000 \\
\text { meters }\end{array}$} & $\begin{array}{l}\text { between } \\
\text { group }\end{array}$ & 28131.149 & 2 & 14065.574 & 7.905 & .000 \\
\hline & & $\begin{array}{l}\text { group within } \\
\text { the statistics }\end{array}$ & 503526.155 & 283 & 1779.244 & & \\
\hline
\end{tabular}

As it was seen from table 3, there was significant difference among boys' 50 meters results, $F$ value was 7.974 , sig. value was $0.000, \mathrm{P}<0.05$. There was significant difference among boys' pull up results, $\mathrm{F}$ value was 18.827 , sig. value was $0.000, \mathrm{P}<0.05$.There was significant difference among boys' 1000 meters results, F value was 7.905, sig. value was $0.000, \mathrm{P}<0.05$.

3.4 Multiple Comparisons and Influencing factors Analysis on Boys' Physical Fitness. Using the method of comparison between the two, we continued analyzing the items showing significant difference.

Table 4 Comparison Between the Two of Significant Difference Items

\begin{tabular}{|c|c|c|c|c|c|c|}
\hline Year & $\begin{array}{l}\text { Depend } \\
\text { ent } \\
\text { variable }\end{array}$ & School(I) & $\operatorname{School}(\mathrm{J})$ & $\begin{array}{c}\text { Mean } \\
\text { difference } \\
(\mathrm{I}-\mathrm{J})\end{array}$ & $\begin{array}{c}\text { Standard } \\
\text { error }\end{array}$ & Sig. \\
\hline \multirow{12}{*}{2015} & \multirow{6}{*}{ pull up } & \multirow{2}{*}{ Affiliated } & Seventh & .174 & .619 & 1.000 \\
\hline & & & Dabancheng & $-3.473^{*}$ & .662 & .000 \\
\hline & & \multirow{2}{*}{ Seventh } & Affiliated & -.174 & .619 & 1.000 \\
\hline & & & Dabancheng & $-3.647^{*}$ & .655 & .000 \\
\hline & & \multirow{2}{*}{$\begin{array}{c}\text { Dabanche } \\
\text { ng }\end{array}$} & Affiliated & $3.473^{*}$ & .662 & .000 \\
\hline & & & Seventh & $3.647^{*}$ & .655 & .000 \\
\hline & \multirow{6}{*}{$\begin{array}{r}50 \\
\text { meters }\end{array}$} & \multirow{2}{*}{ Affiliated } & Seventh & .25579 & .13391 & .171 \\
\hline & & & Dabancheng & $.57212^{*}$ & .14326 & .000 \\
\hline & & \multirow{2}{*}{ Seventh } & Affiliated & -.25579 & .13391 & .171 \\
\hline & & & Dabancheng & .31633 & .14173 & .079 \\
\hline & & \multirow{2}{*}{$\begin{array}{c}\text { Dabanche } \\
\text { ng }\end{array}$} & Affiliated & $-.57212^{*}$ & .14326 & .000 \\
\hline & & & Seventh & -.31633 & .14173 & .079 \\
\hline
\end{tabular}


Table 4, cont.

\begin{tabular}{|c|c|c|c|c|c|}
\hline \multirow{6}{*}{$\begin{array}{l}1000 \\
\text { meters }\end{array}$} & \multirow{2}{*}{ Affiliated } & Seventh & $21.077^{*}$ & 5.894 & .001 \\
\hline & & Dabancheng & $20.420^{*}$ & 6.305 & .004 \\
\hline & \multirow{2}{*}{ Seventh } & Affiliated & $-21.077^{*}$ & 5.894 & .001 \\
\hline & & Dabancheng & -.657 & 6.238 & 1.000 \\
\hline & \multirow{2}{*}{$\begin{array}{c}\text { Dabanche } \\
\text { ng }\end{array}$} & Affiliated & $-20.420^{*}$ & 6.305 & .004 \\
\hline & & Seventh & .657 & 6.238 & 1.000 \\
\hline
\end{tabular}

Using the method of comparison between the two of significant difference items, we can see from table 4 that there was significant difference of pull up between the Dabancheng Middle School and the Seventh School in Urumqi, the sig. value was 0.000, $\mathrm{p}<0.05$. The pull up average results of Dabancheng Middle School were better than other two schools, which was related to the rural boys usually participated in physical labor. There was significant difference of 50 meters between Affiliated Middle School of Xinjiang Normal University and the Dabancheng Middle School, sig. value was $0.000, \mathrm{p}<0.05$. The average results of 50 meters in the Dabancheng Middle School were better, which was maybe related to less learning pressure and more physical activity. There was significant difference of 1000 meters among three middle schools and the average results of the Dabancheng Middle School were better.

\subsection{The Significant Difference Analysis among Girls' Physical Fitness in Three Middle Schools} in 2015

Table 5 ANOVA Analysis among Girls' Physical Fitness in 2015

\begin{tabular}{|c|c|c|c|c|c|c|c|}
\hline Year & Item & & $\begin{array}{l}\text { Sum of } \\
\text { square }\end{array}$ & df & $\begin{array}{c}\text { mean } \\
\text { square }\end{array}$ & $\mathrm{F}$ & Sig. \\
\hline \multirow{10}{*}{2015} & \multirow{2}{*}{$\begin{array}{l}\text { standing } \\
\text { long jump }\end{array}$} & $\begin{array}{l}\text { between } \\
\text { group }\end{array}$ & 4378.286 & 2 & 2189.143 & 2.841 & .060 \\
\hline & & $\begin{array}{c}\text { group } \\
\text { within } \\
\text { the statistics }\end{array}$ & 215785.629 & 280 & 770.663 & & \\
\hline & \multirow{2}{*}{$\begin{array}{l}\text { sitting } \\
\text { body } \\
\text { flexion }\end{array}$} & $\begin{array}{c}\text { between } \\
\text { group }\end{array}$ & 667.132 & 2 & 333.566 & 8.276 & .000 \\
\hline & & $\begin{array}{c}\text { group } \\
\text { within } \\
\text { the statistics }\end{array}$ & 9713.308 & 241 & 40.304 & & \\
\hline & \multirow[b]{2}{*}{50 meters } & $\begin{array}{l}\text { between } \\
\text { group }\end{array}$ & 9.329 & 2 & 4.665 & 7.438 & .001 \\
\hline & & $\begin{array}{c}\text { group } \\
\text { within } \\
\text { the statistics }\end{array}$ & 151.132 & 241 & .627 & & \\
\hline & \multirow{2}{*}{ sits-up } & $\begin{array}{l}\text { between } \\
\text { group }\end{array}$ & 1566.850 & 2 & 783.425 & $\begin{array}{c}18.58 \\
9 \\
\end{array}$ & .000 \\
\hline & & $\begin{array}{c}\text { group } \\
\text { within } \\
\text { the statistics }\end{array}$ & 10157.003 & 241 & 42.145 & & \\
\hline & \multirow[b]{2}{*}{800 meters } & $\begin{array}{l}\text { between } \\
\text { group }\end{array}$ & 11827.731 & 2 & 5913.866 & 6.337 & .002 \\
\hline & & $\begin{array}{c}\text { group } \\
\text { within } \\
\text { the statistics }\end{array}$ & $\begin{array}{c}224905.05 \\
6\end{array}$ & 241 & 933.216 & & \\
\hline
\end{tabular}

As it was seen from table 5, there was significant difference among girls' 50 meters results, $F$ value was 7.438 , sig. value was $0.001, \mathrm{P}<0.05$. There was significant difference among girls' sitting body flexion results, $\mathrm{F}$ value was 8.267 , sig. value was $0.000, \mathrm{P}<0.05$. There was significant difference 
among girls' 800 meters results, $\mathrm{F}$ value was 6.337 , sig. value was $0.000, \mathrm{P}<0.05$. There was significant difference among girls' sits-up results, F value was, sig. value was $18.5890 .000, \mathrm{P}<0.05$.

3.6 Multiple Comparisons and Influencing Factors Analysis on Girls' Physical Fitness. Using the method of comparison between the two, we continued analyzing the items showing significant difference.

Table 6 Comparison Between the Two of Significant Difference Items

\begin{tabular}{|c|c|c|c|c|c|c|}
\hline Year & $\begin{array}{l}\text { Dependent } \\
\text { variable }\end{array}$ & School(I) & $\operatorname{School}(\mathrm{J})$ & $\begin{array}{c}\text { Mean } \\
\text { difference } \\
(\mathrm{I}-\mathrm{J})\end{array}$ & $\begin{array}{l}\text { Standard } \\
\text { error }\end{array}$ & Sig. \\
\hline \multirow{24}{*}{2015} & \multirow{6}{*}{ sits-up } & \multirow{2}{*}{ Affiliated } & Seventh & $-4.462^{*}$ & .937 & .000 \\
\hline & & & Dabancheng & 1.568 & 1.124 & .493 \\
\hline & & \multirow{2}{*}{ Seventh } & Affiliated & $4.462^{*}$ & .937 & .000 \\
\hline & & & Dabancheng & $6.029^{*}$ & 1.112 & .000 \\
\hline & & \multirow{2}{*}{$\begin{array}{c}\text { Dabanche } \\
\text { ng }\end{array}$} & Affiliated & -1.568 & 1.124 & .493 \\
\hline & & & Seventh & $-6.029^{*}$ & 1.112 & .000 \\
\hline & \multirow{6}{*}{$\begin{array}{l}\text { sitting body } \\
\text { flexion }\end{array}$} & \multirow[b]{2}{*}{ Affiliated } & Seventh & $-3.1889^{*}$ & .9168 & .002 \\
\hline & & & Dabancheng & .4501 & 1.099 & $\begin{array}{c}1.00 \\
0\end{array}$ \\
\hline & & \multirow{2}{*}{ Seventh } & Affiliated & $3.1889^{*}$ & .9168 & .002 \\
\hline & & & Dabancheng & $3.6390^{*}$ & 1.087 & .003 \\
\hline & & \multirow{2}{*}{$\begin{array}{c}\text { Dabanche } \\
\text { ng }\end{array}$} & Affiliated & -.4501 & 1.099 & $\begin{array}{c}1.00 \\
0\end{array}$ \\
\hline & & & Seventh & $-3.6390^{*}$ & 1.087 & .003 \\
\hline & \multirow{6}{*}{50 meters } & \multirow[t]{2}{*}{ Affiliated } & Seventh & -.03051 & .11436 & $\begin{array}{c}1.00 \\
0 \\
\end{array}$ \\
\hline & & & Dabancheng & $.46061^{*}$ & .13712 & .003 \\
\hline & & \multirow[t]{2}{*}{ Seventh } & Affiliated & .03051 & .11436 & $\begin{array}{c}1.00 \\
0\end{array}$ \\
\hline & & & Dabancheng & $.49112^{*}$ & .13562 & .001 \\
\hline & & \multirow{2}{*}{$\begin{array}{c}\text { Dabanche } \\
\text { ng }\end{array}$} & Affiliated & $-.46061^{*}$ & .13712 & .003 \\
\hline & & & Seventh & $-.49112^{*}$ & .13562 & .001 \\
\hline & \multirow{6}{*}{800 meters } & \multirow{2}{*}{ Affiliated } & Seventh & 6.211 & 4.411 & .481 \\
\hline & & & Dabancheng & $18.818^{*}$ & 5.290 & .001 \\
\hline & & \multirow{2}{*}{ Seventh } & Affiliated & -6.211 & 4.411 & .481 \\
\hline & & & Dabancheng & 12.607 & 5.232 & .050 \\
\hline & & \multirow{2}{*}{$\begin{array}{l}\text { Dabanche } \\
\text { ng }\end{array}$} & Affiliated & $-18.818^{*}$ & 5.290 & .001 \\
\hline & & & Seventh & -12.607 & 5.232 & .050 \\
\hline
\end{tabular}

Using the method of comparison between the two of significant difference items, we can see from table 6 that there is significant difference of sits-up between the Seventh School in Urumqi and other two schools, the sig. value was $0.000, \mathrm{p}<0.05$, the sits-up results of the Seventh School in Urumqi are better. Through the comparison of sitting body flexion, we find out that there is significant difference among the three schools and the results of the Seventh School in Urumqi are better. Meanwhile, there is significant difference of 50 meters among the three schools, the sig. value respectively was $0.003 、 0.0001, \mathrm{p}<0.05$, the results of the Dabancheng Middle School are better. There is significant difference of 800 meters between the Dabancheng Middle School and Affiliated Middle School of Xinjiang Normal University, the sig. value respectively is $0.0001, \mathrm{p}<0.05$, the results of the Dabancheng Middle School are better.

From the above analysis, we can be see that the eighth grade girls' speed and endurance fitness in rural middle school were better than that of key middle schools, while the waist strength and flexibility fitness of common middle is better than that of key middle school. We find out that the 
same results from the comparison of the eighth grade boys' data. The result is related to the pressure of the key middle schools which makes the students spend more time studying, less time participating in physical activities. From the view of school, the key to solving the problem is to reduce the burden of students, especially do not take up the students physical education, extracurricular sports activities and after-school physical exercise time.

\section{Result and Suggestion}

4.1 From the Physical Fitness Results of Boys in Grade Eight in Three Middle Schools in 2015. The results of pull up are poor, the results of 1000 meters are relatively poor, while the results of sitting body flexion, standing long jump are basically qualified while the results of 50 meters are better. The practice of limb and waist strength are needed.

4.2 From the Physical Fitness Results of Boys in Grade Eight in Three Middle Schools in 2015. The excellent rate and good rate of sits-up are lower, which means the three middle school should pay more attention to the practice of leg and waist strengthen. The endurance fitness is better than before. The results of sitting body flexion and 50 meters are better.

4.3 There were Significant Difference Among Boys' 50 Meters, Pull Up and 1000 Meters in 2015. By continuously comparing between the two, we found that the results of the Dabancheng Middle School were better than the other two school.

4.4 There are Significant Difference Among Girls' 50 Meters, Sits-up, 800Meters and Sitting Body FLexion in 2015. By continuously comparing between the two, we find out that the results of the Dabancheng Middle School are better than the other two school.

4.5 From the View of School, the Key to Solving the Problem is to Reduce the Burden of Students. Especially do not take up the students physical education, extracurricular sports activities and after-school physical exercise time.

\section{Acknowledgements}

This work was financially supported by the State Ethnic Affairs Commission of China for "Support Program for the Young and Middle-Aged Talents" 2014.

\section{Reference}

[1] Shi Jun. Research on the Physical Health of Students in the Rural Middle School in Lian Yungang City. [J]. Journal of Sports Science,2007.

[2] Chinese Student Physical and Health Study Group. A Report on Chinese Students' Physical and Health in 2005 [M]. Beijing High Level Education Press,2008.

[3] Wei Haibin. Study on the Students' Physical and Health of Xibo nationality in Xinjiang Province [D]. Master Thesis of Xinjiang Normal University,2010

[4] National Student Constitutional Health Standard [M], (Revised in 2014) 